\title{
Penerapan Sistem Pengendalian Intern Pemerintah (SPIP) Pada Kabupaten Gorontalo
}

\author{
FITRIANTY PANEO ${ }^{1}$, JULLIE J. SONDAKH ${ }^{2}$, JENNY MORASA ${ }^{3}$
}

\author{
1,2,3Program Magister Akuntansi, Fakultas Ekonomi dan Bisnis Universitas Sam Ratulangi \\ email: fitrianty85@gmail.com¹, julliesondakh@yahoo.com², jennymorasa@hotmail.com³
}

\begin{abstract}
This study aims to analyze the suitability of GICS implementation in Gorontalo District with Government Regulation Number 60 Year 2008 on GICS, the obstacles in the implemention of GICS as well as what efforts have been made to overcome the obstacles of GICS implementation and to increase GICS maturity level in Gorontalo District. This is a qualitative research with case study approach. This study used primary and secondary data. Primary data were obtained from in depth interviews, observation and documentation. On the other hand, secondary data were in the form of documents related to the reseach. The results show that GICSin Gorontalo District has been implemented in accordance to Government Regulation Number 60 Year 2008. However, GICS level 3 (three) maturity targets have not yet been achieved and it means that the implementation of GICS still encounters many obstacles. The obstacles in the application of GICS in Gorontalo District are: 1) insufficient human resource competence, 2) the number of human resources is not in accordance with the needs of organization, 3) limited budget, 4) lack of compliance, 5) evaluation and documentation activities are not maximized yet, and 6) many activities have not been supported by Standard Operational Procedures (SOP). Furthermore, the efforts made to overcome the obstacles of GICS implementation are by 1) encouraging human resources development program such as substantive training and training of their own office, 2) maximizing budget, 3) establishing effective communications, 4) increasing the number of auditors and 5) building organizational commitment.
\end{abstract}

Keywords: Implementation of Government Internal Control System (GICS), GICS Maturity Result, Constraints and efforts

Abstrak. Penelitian ini bertujuan untuk menganalisis kesesuaian penerapan SPIP pada Kabupaten Gorontalo dengan PP 60 Tahun 2008 tentang SPIP, mengidentifikasi dan menganalisis kendala dalam penerapan SPIP serta upaya-upaya apa yang dilakukan dalam mengatasi kendala penerapan SPIP untuk peningkatan tingkat maturitas SPIP di Kabupaten Gorontalo. Penelitian ini menggunakan metode kualitatif dengan pendekatan studi kasus. Data yang digunakan adalah data primer, yang diperoleh melalui wawancara mendalam, observasi dan studi dokumentasi. Serta data sekunder berupa dokumen-dokumen terkait dengan penelitian. Hasil penelitian menunjukkan bahwa secara umum penerapan SPIP pada Kabupaten Gorontalo telah sesuai dengan PP 60 Tahun 2008 tentang SPIP. Namun, belum tercapainya target level 3 (tiga) maturitas SPIP di Kabupaten Gorontalo mengindikasikan bahwa penerapan SPIP masih mengalami banyak kendala. Kendala-kendala dalam penerapan SPIP yaitu; 1) kompetensi SDM belum memadai, 2) kuantitas SDM belum sesuai dengan kebutuhan organisasi, 3) terbatasnya anggaran, 4) kurangnya kepatuhan, 5) belum maksimalnya kegiatan evaluasi dan dokumentasi, dan 6) terdapat kegiatan yang belum didukung dengan Standar Operasional Prosedur (SOP). Upaya-upaya yang dilakukan untuk mengatasi kendala-kendala dalam penerapan SPIP yaitu: 1) program pengembangan SDM melalui diklat substantif dan pelatihan kantor sendiri, 2) memaksimalkan anggaran, 3) membangun komunikasi yang efektif, 4) menambah jumlah auditor dan 5) membangun komitmen organisasi.

Kata kunci: Penerapan Sistem Pengendalian Intern Pemerintah (SPIP), Tingkat Maturitas Penyelenggaraan SPIP, Kendala dan Upaya.

\section{Pendahuluan}

Lahirnya Undang-Undang Nomor 17 Tahun 2003 tentang Keuangan Negara, Undang-Undang Nomor 1 Tahun 2004 tentang Perbendaharaan Negara dan Undang-Undang Nomor 15 tahun 2004 tentang Pemeriksaan Pengelolaan dan Tanggung Jawab Keuangan Negara merupakan tonggak dimulainya reformasi di bidang keuangan. Dalam Undang-Undang Nomor 1 Tahun 2004 tentang Perbendaharaan Negara pasal 58 ayat (1) dinyatakan bahwa:

1. Dalam rangka meningkatkan kinerja, transparansi dan akuntabilitas pengelolaan keuangan negara, Presiden selaku Kepala Pemerintahan mengatur dan menyelenggarakan sistem pengendalian intern di lingkungan pemerintah secara menyeluruh.

2. Sistem pengendalian intern sebagaimana dimaksud pada ayat (1) ditetapkan dengan Peraturan Pemerintah.

Dari pemikiran tersebut, diterbitkan Peraturan Pemerintah Nomor 60 Tahun 2008 tentang Sistem Pengendalian Intern Pemerintah (SPIP) yang mewajibkan menteri, kepala lembaga, gubernur, bupati 
dan walikota untuk menerapkan SPIP di lingkungannya. Sistem Pengendalian Intern perlu mempertimbangkan aspek biaya-manfaat (cost and benefit), sumber daya manusia, kejelasan kriteria pengukuran efektivitas, dan perkembangan teknologi informasi serta dilakukan secara komprehensif. Sistem pengendalian intern dilakukan secara kontinyu dan terintegrasi mulai dari pimpinan dan seluruh pegawai untuk memberikan keyakinan yang memadai bahwa untuk mencapai tujuan organisasi dilakukan melalui penyelenggaraan kegiatan yang efektif dan efisien, pelaporan keuangan yang andal, mengamankan aset negara dan kepatuhan terhadap peraturan perundang-undangan.

Berdasarkan Ikhtisar Hasil Pemeriksaan Semester (IHPS) I BPK Tahun 2016, jumlah LKPD yang memperoleh opini WTP mencapai 58\%, namun sampai saat ini BPK masih menemukan permasalahan lain yang terkait dengan kelemahan SPI dan ketidakpatuhan terhadap perundang-undangan. Hasil pemeriksaan BPK atas 533 LKPD, ditemukan 6.150 kasus terkait kelemahan SPI yang terdiri dari kelemahan sistem pengendalian akuntansi dan pelaporan sebanyak 2.353 kasus (38,26\%), kelemahan sistem pengendalian pelaksanaan anggaran pendapatan dan belanja sebanyak 2.450 kasus (39,84\%) dan kelemahan struktur pengendalian intern sebanyak 1.347 kasus (21,90\%). Hal tersebut tidak hanya terjadi secara nasional, namun merupakan sebagai keterwakilan dari permasalahan dalam pemerintah, baik pusat maupun daerah. Kondisi ini membuktikan bahwa penerapan sistem pengendalian intern di pemerintah masih mengalami banyak hambatan.

Untuk mengukur keberhasilan penerapan SPIP dilakukan penilaian tingkat maturitas penyelenggaraan SPIP. Tingkat maturitas penyelenggaraan SPIP adalah tingkat kematangan/kesempurnaan penyelenggaraan SPIP dalam mencapai tujuan pengendalian intern sesuai dengan PP 60 Tahun 2008 tentang SPIP. Semakin tinggi nilai tingkat maturitas SPIP, maka semakin baik pula penerapan SPIP. Karakteristik tingkat maturitas SPIP terbagi dalam enam tingkatan kematangan yaitu: belum ada (level 0), rintisan (level 1), berkembang (level 2), terdefinisi (level 3), terkelola dan terukur (level 4) dan optimum (level 5). Menurut data BPKP s/d 30 Juni 2017, capaian level 3 maturitas SPIP untuk pemerintah provinsi baru mencapai 14\% dan untuk pemerintah kabupaten/kota baru mencapai $8 \%$. Kondisi ini masih jauh dari target yang ditetapkan pemerintah dalam RPJMN 2015-2019 bahwa untuk pemerintah provinsi sebesar 85\% dan pemerintah kabupaten/kota sebesar $70 \%$.

Terkait dengan penyelenggaraan SPIP, Pemerintah Kabupaten Gorontalo telah menerbitkan Peraturan Bupati Nomor 10 Tahun 2010 tentang Penyelenggaraan SPIP di Kabupaten Gorontalo yang kemudian didukung dengan Surat Keputusan Bupati Gorontalo Nomor 99/25/II/2010 tentang Pembentukan Satuan Tugas SPIP. Satgas SPIP merupakan perwakilan dari masing-masing SKPD yang menjadi perpanjangan tangan dari inspektorat dan diharapkan bisa melaksanakan pengawasan intern secara kontinyu dan terstruktur di setiap satuan kerjanya. Berdasarkan Surat Sekretaris Daerah Nomor: 800/DPPKAD/078/2011 tanggal 9 September 2011, Pemerintah Kabupaten Gorontalo melakukan Pemetaan atau diagnostic assessment di SKPD yang menjadi pilot project penerapan SPIP di Kabupaten Gorontalo. Hasil Pemetaan tersebut menunjukkan bahwa masih banyak area yang perlu perbaikan (area of improvement) terkait penerapan SPIP di Kabupaten Gorontalo. Mulai dari sosialisasi SPIP yang belum mencakup seluruh pegawai, masih lemahnya pencapaian tujuan SPIP serta perbaikan di semua unsur SPIP.

Adanya kesenjangan yang terjadi juga terlihat dari laporan hasil penilaian tingkat maturitas penyelenggaraan SPIP pada Kabupaten Gorontalo oleh BPKP Perwakilan Provinsi Gorontalo Nomor: LAP-76/PW31/3/2016 tanggal 21 Juni 2016, bahwa skor maturitas SPIP pada Kabupaten Gorontalo sebesar 2,1034 dan masih berada pada level berkembang. Hal tersebut menunjukkan bahwa Pemerintah Kabupaten Gorontalo telah sepenuhnya menetapkan kebijakan dan prosedur pengendalian serta mengkomunikasikannya di lingkungan Pemerintah Kabupaten Gorontalo. Namun belum sepenuhnya melaksanakan kebijakan dan prosedur pengendalian dan belum sepenuhnya melakukan evaluasi atas penerapan kebijakan dan prosedur pengendalian tersebut.

Dari hasil penilaian tersebut, ditemukan bahwa permasalahan terkait SPIP terjadi pada 4 (empat) unsur SPIP yaitu unsur lingkungan pengendalian, penilaian risiko, informasi dan komunikasi dan pemantauan yang lebih rinci terjadi pada 8 (delapan) sub unsur yakni sub unsur komitmen terhadap kompetensi, struktur organisasi sesuai kebutuhan, delegasi wewenang dan tanggung jawab, identifikasi risiko, analisis risiko, informasi yang relevan, pemantauan berkelanjutan dan evaluasi terpisah. Untuk unsur kegiatan pengendalian, tidak ditemukan permasalahan dalam unsur ini. Kondisi ini belum memenuhi target yang ditetapkan pemerintah dalam Rencana Pemerintah Jangka Menengah Nasional (RPJMN) 2015-2019 bahwa tingkat maturitas penyelenggaraan SPIP berada pada "level 3" atau level "terdefinisi”. 


\section{Model Analisis}

Model analisis dalam penelitian ini menggunakan model analisis Milles dan Huberman dalam Sugiyono (2015:91) yang terdiri atas data reduction, data display, dan drawing conclusion/verification dengan menganalisis kesesuaian penerapan Sistem Pengendalian Intern Pemerintah (SPIP) di Kabupaten Gorontalo dengan PP 60 Tahun 2008 tentang Sistem Pengendalian Intern Pemerintah (SPIP) dan kendala-kendala dalam penerapan SPIP serta upaya-upaya dalam mengatasi kendala penerapan SPIP untuk peningkatan tingkat maturitas SPIP di Kabupaten Gorontalo.

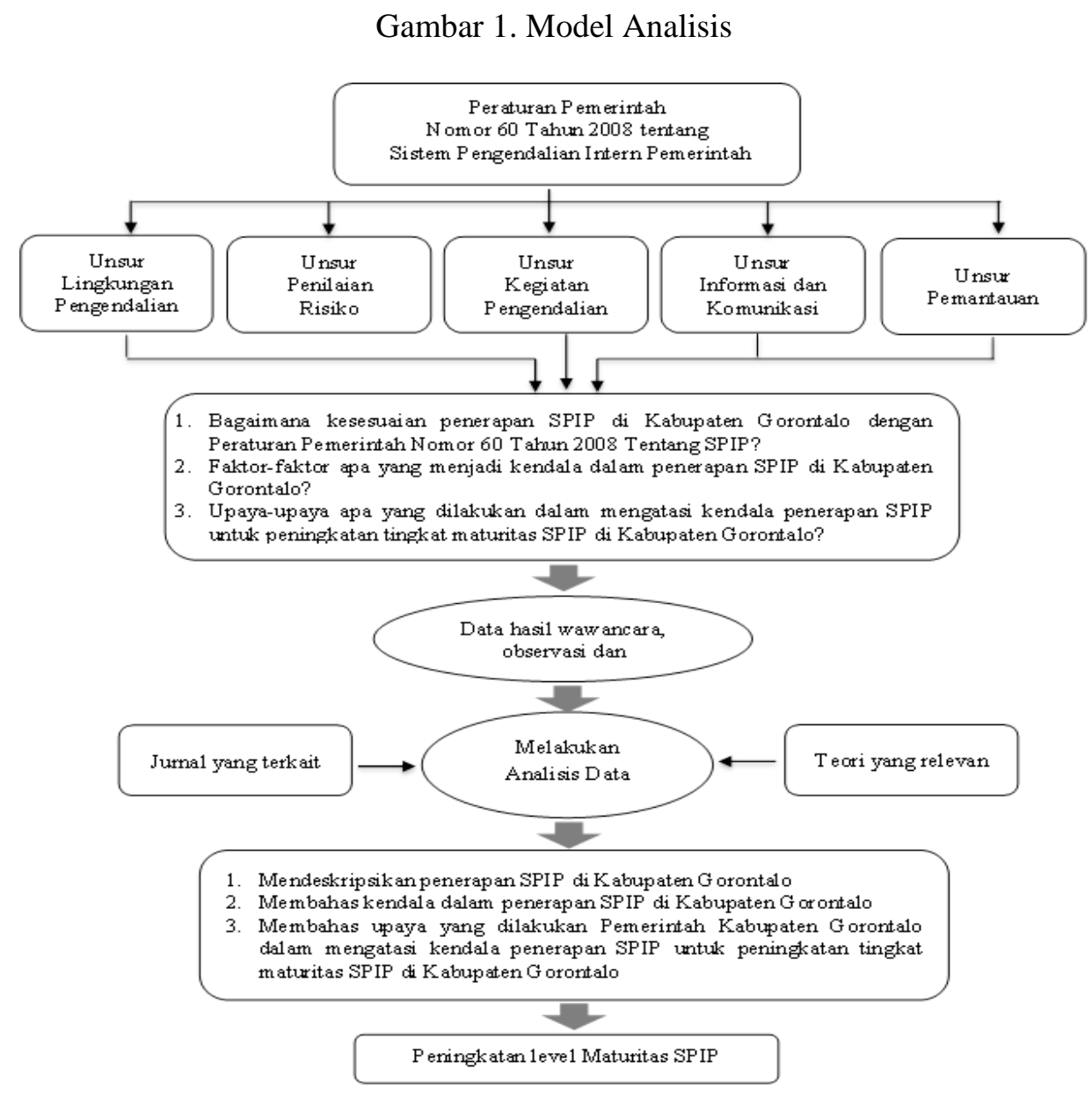

\section{Metode Penelitian}

Penelitian ini menggunakan metode penelitian kualitatif dengan pendekatan studi kasus (case study) berdasarkan alasan yaitu untuk menggali informasi mendalam untuk menganalisis secara cermat dan lebih terinci penerapan SPIP, faktor apa yang menjadi kendala dalam penerapan SPIP serta upaya yang telah dilakukan oleh Pemerintah Kabupaten Gorontalo. Gunawan (2016:112) menyatakan penelitian studi kasus memusatkan diri secara intensif pada satu objek tertentu yang mempelajarinya sebagai suatu kasus. Penelitian studi kasus dimaksudkan untuk mempelajari secara intensif, tentang latar belakang masalah keadaan dan posisi suatu peristiwa yang sedang berlangsung saat ini, serta interaksi lingkungan unit sosial tertentu yang bersifat apa adanya (given).

Sumber data yang digunakan dalam penelitian ini terdiri dari data primer dan data sekunder. Data primer, yaitu data yang diperoleh langsung dari informan. Data sekunder, yaitu data yang diperoleh dari dokumen-dokumen yang berkaitan dengan pembahasan, literatur serta sumber lainnya yang berkaitan dengan fokus penelitian berupa profil Pemerintah Kabupaten Gorontalo, laporan hasil penilaian maturitas SPIP tahun 2016 dan regulasi tentang penyelenggaraan SPIP.

Teknik pengumpulan data dalam penelitian ini adalah wawancara mendalam (indepth interviews), observasi (observation) dan studi dokumentasi. Informan kunci berjumlah 14 (empatbelas) orang yang ditentukan secara purposive sampling dan terbagi dalam 2 (dua) kelompok yaitu: sekretariat satgas SPIP kabupaten dan satgas SPIP SKPD. Kriteria informan kunci yang dipilih yaitu Aparatur Sipil Negara (ASN) yang dianggap memahami proses penerapan SPIP di Kabupaten Gorontalo khususnya di SKPD masing-masing, dan secara struktural mempunyai wewenang sehubungan dengan pelaksanaan tugas dan 
fungsi di SKPD serta mereka yang mempunyai waktu memadai untuk dimintai informasi terkait dengan fokus penelitian.

Dalam penelitian ini proses analisis data menggunakan tahapan yang dikemukakan oleh Milles dan Huberman dalam Sugiyono (2015:91) yang terdiri atas data reduction, data display, dan drawing conclusion/verification yang dilakukan secara interaktif dan berlangsung secara terus menerus sampai tuntas, sehingga datanya mencapai jenuh. Uji keabsahan data yang digunakan dalam penelitian ini meliputi uji credibility (validitas internal) dengan melakukan triangulasi sumber dan triangulasi teknik, uji transferability (validitas eksternal) dilakukan dengan menunjukkan derajat ketepatan atau dapat diterapkannya hasil penelitian ke populasi dimana sampel itu diambil, uji dependability (realiabilitas) dilakukan dengan cara pemeriksaaan kembali terhadap keseluruhan proses penelitian yang dilakukan oleh pembimbing mulai dari menentukan fokus masalah, sumber data, analisis data dan melakukan uji keabsahan data sampai pada pembuatan kesimpulan atau laporan akhir serta uji confirmability (objektivitas) berarti menguji hasil penelitian, dikaitkan dengan proses yang dilakukan. Bila hasil penelitian merupakan fungsi dari proses penelitian yang dilakukan, maka penelitian tersebut telah memenuhi standar konfirmability. Dalam penelitian, jangan sampai proses tidak ada, tetapi hasilnya ada.

\section{Analisis dan Pembahasan}

Penelitian ini dilakukan sejak bulan Juni s/d bulan September 2017 dengan melakukan wawancara mendalam, studi dokumentasi dan observasi langsung di SKPD yang menjadi fokus penelitian. Dalam penelitian ini, digunakan instrumen-instrumen pendukung seperti buku catatan, alat perekam berupa audio, kamera untuk mendokumentasikan kegiatan di lapangan, dan laptop untuk menunjang penulisan hasil penelitian. Selain itu, sebagai referensi tambahan yakni pengalaman peneliti sebagai satgas SPIP selama 5 (lima) tahun di salah satu SKPD di Kabupaten Gorontalo.

\section{Kesesuaian Penerapan SPIP di Kabupaten Gorontalo dengan PP 60 Tahun 2008 tentang SPIP}

Berdasarkan laporan hasil penilaian BPKP Tahun 2016, bahwa tingkat maturitas penyelenggaraan SPIP di Kabupaten Gorontalo berada pada level 2 atau "berkembang”. Pada level ini, Kabupaten Gorontalo telah sepenuhnya menetapkan kebijakan dan prosedur pengendalian serta mengkomunikasikannya di lingkungan Pemerintah Kabupaten Gorontalo. Namun belum sepenuhnya melaksanakan kebijakan dan prosedur pengendalian dan belum sepenuhnya melakukan evaluasi atas penerapan kebijakan dan prosedur pengendalian tersebut. Hal ini berarti dalam penerapannya, Pemerintah Kabupaten Gorontalo masih mengalami kendala-kendala yang dihadapi untuk mencapai target level 3 sesuai dengan target nasional dalam RPJMN 2015-2019. Kesesuaian penerapan SPIP di Kabupaten Gorontalo dengan PP 60 Tahun 2008 tentang SPIP, pada masing-masing unsur SPIP diuraikan pada pembahasan berikut :

\section{Unsur Lingkungan Pengendalian}

a. Komitmen Terhadap Kompetensi

Penerapan komitmen terhadap kompetensi diharapkan bisa mendorong pencapaian tujuan organisasi karena fungsi-fungsi yang ada di organisasi diisi oleh SDM yang mempunyai keahlian, pengetahuan dan sikap yang diperlukan untuk penyelesaian kegiatan dalam organisasi. Pemerintah Kabupaten Gorontalo telah menyusun kebijakan terkait komitmen terhadap kompetensi berdasarkan analisis beban kerja dan telah dikomunikasikan di seluruh SKPD. Dalam proses penempatan pegawai, seharusnya Kabupaten Gorontalo berpedoman pada standar kompetensi yang dipersyaratkan. Namun hal itu belum sepenuhnya diterapkan sebagaimana mestinya.

Dari hasil penelitian, ditemukan kendala kompetensi SDM yang masih terbatas. Beberapa penempatan pegawai di SKPD justru belum sesuai dengan standar kompetensi yang dipersyaratkan seperti tidak ada kaitan antara basic pendidikan atau diklat teknis yang pernah diikuti dengan jabatan yang baru. Konsep the right man and the right place belum sepenuhnya dilaksanakan dalam promosi atau mutasi jabatan. Hal ini berdampak pada tidak efektifnya pemanfaatan pegawai sehingga kemungkinan terjadi rangkap tugas oleh pegawai yang berkompeten dan di sisi lain justru ada pegawai yang "pasif” karena ketidaktahuannya atau ketidakmampuannya melaksanakan pekerjaan sesuai tugas pokok dan fungsinya. Selain dari segi kompetensi SDM, pada penelitian ini juga ditemukan kuantitas SDM yang belum memadai, hal ini tentunya berdampak pada kualitas kinerja pegawai yang dihasilkan.

Menurut Sedarmayanti (2011:144) SDM adalah seseorang yang siap, mau dan mampu memberi sumbangan terhadap usaha pencapaian tujuan organisasi. Sementara kompetensi menurut Edison, 
Anwar dan Komariah (2016:142) adalah kemampuan individu untuk melaksanakan suatu pekerjaan dengan benar dan memiliki keunggulan yang didasarkan pada hal-hal yang menyangkut pengetahuan (knowledge), keahlian (skill) dan sikap (attitude). Sehingga dapat disimpulkan, kompetensi dianggap penting dalam mencapai tujuan organisasi karenanya pegawai harus mampu dan paham apa yang harus ia kerjakan. Penelitian ini sejalan dengan hasil penelitian sebelumnya yang dilakukan oleh Kusmandhani (2015) ditemukan bahwa salah satu yang menjadi hambatan penerapan SPIP adalah belum terdapat standar kompetensi sebagai dasar penempatan pegawai di Kantor Pelayanan Perbendaharaan Negara Jakarta IV.

b. Struktur Organisasi Sesuai Kebutuhan

Torang (2012:86) mendefinisikan struktur organisasi adalah susunan antar hubungan satuansatuan organisasi yang di dalamnya terdapat pemimpin (pengurus), tugas serta wewenangnya masing-masing yang mempunyai peranan tertentu dalam kesatuan yang untuk mencapai tujuan organisasi. Pemerintah Kabupaten Gorontalo telah menyusun Peraturan Daerah Nomor 9 Tahun 2016 tentang Pembentukan dan Susunan Perangkat Daerah Kabupaten Gorontalo, kemudian dijabarkan lagi dalam Peraturan Bupati tentang Kedudukan, Susunan Organisasi, Tugas dan Fungsi dan Tata Kerja masing-masing SKPD. Dari struktur organisasi yang baru, dijabarkan lagi dalam bentuk uraian tugas masing-masing pegawai. Salah satu bentuk pengembangan berkelanjutan yang dilakukan oleh Kabupaten Gorontalo adalah membuat surat perjanjian kontrak kinerja secara berjenjang mulai dari Bupati ke pimpinan SKPD, dari pimpinan SKPD ke eselon III, dari eselon III ke Eselon IV dan dari eselon IV ke staf.

Namun hasil penelitian menunjukkan bahwa, kendala dalam penerapan SPIP di Kabupaten Gorontalo terkait struktur organisasi adalah kuantitas pegawai yang belum sesuai dengan kebutuhan organisasi. Meskipun telah dilakukan pembagian tugas, masih terdapat kesenjangan antara beban pekerjaan dengan jumlah pegawai. Akibatnya terjadi lembur untuk menyelesaikan tugas dan perangkapan tugas dan tanggung jawab lebih dari satu.

Berdasarkan uraian tersebut dapat disimpulkan bahwa, penyelenggaraan sub unsur pembentukan struktur organisasi sesuai kebutuhan bertujuan agar terbentuknya struktur organisasi yang sesuai dengan peraturan perundang-undangan, efektif dan efisien, terdapat kejelasan kewenangan dan tanggung jawab serta personil organisasi yang sesuai. Sasaran akhirnya, pimpinan dan bawahan bisa sama-sama memahami pengendalian intern yang menjadi tanggung jawabnya serta diharapkan pegawai tidak bekerja lembur secara berlebihan dan tidak merangkap tugas dan tanggung jawab. Hasil ini sejalan dengan penelitian sebelumnya yang dilakukan Kamarudin (2015) terkait evaluasi SPIP dalam pemungutan retribusi dan parkir pada Kabupaten Sleman, bahwa salah satu masalah yang ditemukan adalah pegawai yang menangani urusan pemungutan retribusi pada Kabupaten Sleman hanya berjumlah 4 (empat) orang.

c. Delegasi Wewenang dan Tanggung Jawab

Pendelegasian wewenang dalam Modul BPKP (2009:6) adalah proses pengalokasian wewenang kepada orang lain secara sah untuk melakukan berbagai aktivitas yang ditujukan untuk pencapaian tujuan organisasi. Sasaran yang ingin dicapai dalam pendelegasian wewenang dan tanggung jawab ini adalah wewenang telah diberikan secara tepat sesuai dengan tingkat tanggung jawabnya, pelaksanaannya dilakukan sesuai prosedur serta pegawai yang diberi wewenang memahami bahwa wewenang dan tanggung jawab yang diterimanya terkait dengan pihak lain dalam instansi pemerintahan. Pemerintah Kabupaten Gorontalo, melalui Badan Kepegawaian dan Diklat telah menyusun pedoman tentang mekanisme pelaksanaan pendelegasian dan wewenang yang telah disosialisasikan melalui satgas SPIP SKPD dan diperkuat lagi dalam bentuk surat edaran ke SKPD di lingkungan Kabupaten Gorontalo.

Berdasarkan hasil penelitian, kendala yang terjadi dalam penerapan SPIP terkait delegasi wewenang dan tanggung jawab, adalah sikap tidak patuh terhadap kebijakan atau SOP. Masih terdapat SKPD yang justru belum membuat surat penunjukan pelaksana tugas selama pimpinan tidak berada ditempat, dengan alasan lupa atau sibuk serta masih bisa berkoordinasi dengan pimpinan lewat telepon. Selain itu ada SKPD yang telah membuat surat penunjukkan pelaksana tugas, tetapi belum membuat laporan secara tertulis sebagai umpan balik dari penerima wewenang. Ada SKPD yang justru menganggap bahwa delegasi wewenang dan tanggung jawab berjalan secara otomatis, tanpa perlu membuat surat penunjukkan beserta laporannya. Hal ini berjalan terus, karena memang belum ada sanksi yang diberikan.

Menurut Parsons (2006:518) menyatakan bahwa ada tiga alasan dasar mengapa orang di dalam organisasi mau mematuhi aturan, disiplin, perintah atau kebijakan: pertama, mereka melakukannya 
karena merasa setuju, cinta atau moralitas. Mereka tidak perlu dipaksa untuk melakukan sesuatu karena memang mereka ingin melakukannya. Kedua, orang mau patuh karena takut. Jika mereka tidak melaksanakan apa yang diperintahkan, mereka takut akan konsekuensinya. Ketiga, mereka patuh mungkin karena demi kepentingan uang atau imbalan keuntungan (remunerative). Meskipun mereka membencinya, mereka tetap melakukannya karena motif imbalan uang yang akan mereka terima. Hal ini sejalan dengan penelitian sebelumnya yang dilakukan oleh Mahiri (2016) pada Dinas Pendidikan Kabupaten Majalengka, menyimpulkan bahwa pendelegasian wewenang yang tepat berpengaruh pada prestasi kerja pegawai.

\section{Unsur Penilaian Risiko}

a. Identifikasi Risiko

Dalam Modul BPKP (2009:8), risiko diartikan sebagai kemungkinan kejadian yang merugikan. Ada 3 (tiga) unsur penting yang menunjukkan apakah suatu potensi kejadian dapat disebut risiko, yaitu (a) merupakan kejadian; (b) kejadian tersebut masih merupakan kemungkinan, jadi dapat saja terjadi, atau tidak terjadi; (c) jika sampai terjadi, ada akibat yang ditimbulkan yaitu kerugian. Pemerintah Kabupaten Gorontalo telah menyusun pedoman penilaian risiko yang termuat dalam Peraturan Bupati No. 66 Tahun 2016 Tentang Penyelenggaraan SPIP di Kabupaten Gorontalo yang menjadi dasar bagi SKPD dalam melakukan proses penilaian risiko di instansinya.

Masing-masing SKPD telah melakukan identifikasi risiko, namun masih terbatas pada 1 (satu) kegiatan utama di SKPD. Selain itu, di beberapa SKPD pelaksanaan identifikasi risiko hanya dilakukan oleh satgas SPIP saja yang kemudian dikonsultasikan dengan pimpinan SKPD. Dalam menyusun register risiko, seharusnya melibatkan penanggung jawab kegiatan yang paham seluk beluk kegiatan yang akan diidentifikasi risikonya. Hasil penelitian menunjukkan bahwa kendala yang terjadi terkait unsur penilaian risiko salah satunya adalah kompetensi pegawai. Terbatasnya pemahaman pegawai yang terlibat dalam proses penilaian risiko di SKPD, mengakibatkan pegawai mengalami kesulitan dalam mengidentifikasi dan menganalisis risiko-risiko yang mungkin terjadi.

Menurut Wibowo (2015:94), kemampuan atau ability adalah kapabilitas intelektual, emosional dan fisik untuk melakukan berbagai aktivitas sehingga menunjukkan apa yang dapat dilakukan untuk mencapai tujuannya. Satgas SPIP SKPD diharapkan mampu menjelaskan kepada pegawai yang terlibat dalam pelaksanaan penilaian risiko, bagaimana proses penilaian risiko seharusnya dilakukan. Hal ini karena tidak semua pegawai yang terlibat mampu mengidentifikasi risiko. Penilaian risiko bertujuan untuk memberikan gambaran peta risiko yang mungkin terjadi dalam pencapaian program dan kegiatan di SKPD serta memberikan masukan mengenai penanganan risiko yang mungkin terjadi.

b. Analisis Risiko

Berdasarkan hasil identifikasi risiko, selanjutnya dilakukan analisis risiko. Analisis risiko yang dimaksud dalam Modul BPKP (2009:3) mencakup penentuan dampak dan kemungkinan (probabilitas) risiko, tingkat risiko, prioritas risiko, dan respon risiko. Pemerintah Kabupaten Gorontalo telah menyusun Rencana Tindak Pengendalian (RTP) di masing-masing SKPD berdasarkan register risiko yang dihasilkan dari kegiatan identifikasi risiko. RTP yang disusun masih terbatas pada 1 (satu) kegiatan SKPD dan hanya pegawai tertentu yang terlibat dalam proses penyusunannya.

Dari hasil penelitian, ditemukan bahwa dalam pelaksanaan kegiatan analisis risiko di SKPD belum didukung dengan dokumentasi dan evaluasi yang memadai. Terdapat beberapa SKPD belum melakukan pemutakhiran dan pendokumentasian atas register risiko dan rencana tindak pengendalian (RTP) yang telah disusun. Hal ini menjadi kendala dalam penerapan SPIP, karena kita tidak bisa mengukur sejauh mana SPIP itu diterapkan, apa dampak dan manfaat yang diperoleh dari penerapan SPIP. Sedangkan tanpa pendokumentasian yang baik, kita tidak bisa memberikan bukti konkrit bagaimana pengendalian intern itu dilaksanakan.

Dalam Modul BPKP (2009:21) tujuan analisis risiko adalah untuk menetapkan level risiko dan sifat risiko di mana level risiko ditentukan dengan mengkombinasikan konsekuensi dan kemungkinan. Dengan kata lain, tujuan analisis risiko adalah untuk memisahkan risiko minor yang dapat diterima dan risiko besar, sehingga diketahui profil dan peta dari risiko-risiko yang ada, dan yang akan digunakan sebagai bantuan dalam evaluasi dan strategi penanganan risiko. Sementara evaluasi menurut Mulyadi (2016:128) merupakan salah satu tahapan dalam analisis kebijakan publik yang bertujuan untuk menilai secara keseluruhan bahwa suatu kebijakan publik yang akan, sedang dan sudah dilaksanakan berhasil mencapai tujuan, sasaran dan dampak secara optimal bagi 
kepentingan masyarakat. Selain evaluasi, perlu dilakukan kegiatan pendokumentasian terkait penerapan suatu kebijakan. Pendokumentasian dilakukan agar kegiatan dapat dikendalikan dan dievaluasi. Dalam Modul BPKP (2009:12) dokumentasi diartikan sebagai suatu proses pemberian bukti, atau bahan/materi yang digunakan dalam berkomunikasi dan pemberian dokumen. Tanpa dokumentasi yang baik, kita tidak bisa memberikan bukti konkrit bagaimana pengendalian intern itu dilaksanakan.

Unsur Kegiatan Pengendalian

Dalam unsur ini, sudah tidak ditemukan lagi permasalahan dalam penerapan SPIP.

Unsur Informasi dan Komunikasi

Informasi yang Relevan

Informasi merupakan poin penting dalam kegiatan pengendalian intern karena menjadi sarana dalam mengkomunikasikan pengendalian yang telah diterapkan dalam instansi pemerintah. Menurut Fahmi (2015:207) sistem adalah seperangkat komponen yang berada dalam suatu organisasi yang saling berhubungan dalam menunjang aktivitas kinerja organisasi tersebut. Dalam PP 60 Tahun 2008 pasal 42 ayat (2) huruf b mengamanatkan kepada pimpinan instansi pemerintah untuk mengelola, mengembangkan dan memperbaharui sistem informasi secara terus menerus.

Dalam penelitian ini, ditemukan bahwa penerapan sub unsur informasi yang relevan di Kabupaten Gorontalo secara umum telah sesuai dengan PP No. 60 Tahun 2008. Pemerintah Kabupaten Gorontalo telah memiliki kebijakan dan prosedur kehumasan tentang identifikasi kebutuhan informasi SPIP yang ditetapkan secara formal. Sebagian besar SKPD telah memiliki rancangan perekaman dan penyimpanan data sesuai dengan tupoksinya masing-masing. Sebagai contoh BKD-Diklat menggunakan aplikasi SIMPEG, di Inspektorat ada aplikasi SIM-TL, Dinas Kesehatan menyediakan bank data kesehatan, Badan Keuangan menggunakan aplikasi SIMDA, Bagian Organisasi dan RB menggunakan aplikasi E-Sista. Semua penyediaan informasi berbasis aplikasi tersebut, bertujuan untuk menunjang kegiatan pelayanan yang ada di masing-masing SKPD.

Namun kendala yang ditemukan dalam penelitian ini adalah keterbatasan anggaran dalam membangun dan menerapkan sub-sub unsur SPIP di SKPD. Misalnya terkait penyediaan sistem informasi sebagai penunjang kegiatan SKPD, terkadang untuk pemeliharaan dan pengembangannya tidak tersentuh anggaran secara maksimal. Selain keterbatasan anggaran, kendala lain yang ditemukan adalah terbatasnya kompetensi pengelola sistem informasi yang ada di SKPD. Kehadiran teknologi dapat memudahkan kegiatan pemerintahan, secanggih apapun teknologi yang digunakan pasti membutuhkan manusia yang mampu mengoperasikannya.

Unsur Pemantauan

a. Pemantauan Berkelanjutan

Dalam Modul BPKP (2009:5) pemantauan pengendalian intern pada dasarnya adalah memastikan bahwa sistem pengendalian intern pada suatu instansi pemerintah berjalan sesuai dengan yang diharapkan dan perbaikan-perbaikan yang diperlukan telah dilaksanakan sesuai dengan perkembangan. Pemerintah Kabupaten Gorontalo telah membentuk Satgas SPIP SKPD yang berkewajiban melakukan pemantauan secara independen di masing-masing SKPD. Selain satgas SPIP, pimpinan SKPD juga berkewajiban melakukan pemantauan berkelanjutan atas pelaksanaan kegiatan di SKPD. Pemantauan ini berupa evaluasi kinerja pegawai yang dilakukan melalui rapatrapat atau pengarahan pada saat apel kerja. Khusus untuk Inspektorat, kegiatan pemantauan berkelanjutan merupakan tupoksi utama yang termuat dalam Program Kerja Pemeriksaan Tahunan (PKPT).

Meskipun dalam penerapannya telah berjalan sebagaimana mestinya, namun belum ada dokumentasi yang memadai atas kegiatan pemantauan yang dilakukan. Masih terdapat SKPD yang mengabaikan dokumen pendukung seperti belum dibuatkannya notulen rapat, laporan tertulis pelaksanaan apel dan sebagainya. Untuk Inspektorat, belum dibuatkannya berita acara kesepakatan antara auditor dengan obrik atas temuan hasil pemeriksaan. Selama ini kegiatan itu dilakukan, tetapi belum didukung dengan dokumentasi yang baik.

Kendala yang ditemukan dalam penelitian ini, terkait pemantauan berkelanjutan adalah jumlah auditor yang belum memadai. Kondisi ini menunjukkan bahwa Inspektorat memiliki beban kerja yang tinggi. Ini terlihat dari luasnya cakupan wilayah pemeriksaan dan banyaknya obyek pemeriksaan di Kabupaten Gorontalo yang tidak seimbang dengan jumlah auditor yang ada. Hal ini 
berdampak pada waktu penyelesaian tugas pemeriksaan melewati dari target yang telah ditetapkan dan penentuan obyek pemeriksaan hanya berdasarkan sampel. Berdasarkan tugas dan fungsinya, Inspektorat Kabupaten Gorontalo memiliki tanggung jawab dan kewajiban untuk melakukan pengawasan pada seluruh entitas yang berada di wilayah Pemerintah Kabupaten Gorontalo yang terdiri dari 32 Sekretariat/Dinas/Badan, 9 Bagian, 19 Kecamatan, 191 Desa, 14 Kelurahan, 21 Puskesmas, dan 287 Sekolah Dasar, 126 Sekolah Menengah Pertama, 14 Sekolah Menengah Atas dan 11 Sekolah Menengah Kejuruan. Banyaknya entitas yang diperiksa, tidak seimbang dengan jumlah auditor yang ada yakni 16 orang Auditor Ahli Pratama/Auditor Terampil (anggota tim), 1 orang Auditor Ahli Muda (Ketua Tim) dan 3 orang Auditor Ahli Madya (Pengendali Teknis).

b. Evaluasi Terpisah

Pengertian evaluasi terpisah dalam Modul BPKP (2009:6) adalah kegiatan membandingkan pelaksanaan SPIP dengan standar yang telah ditentukan dalam daftar uji atau instrumen lain, yang telah ditetapkan pimpinan instansi pemerintah atau pelaksana evaluasi terpisah. Kegiatan ini meliputi penilaian sendiri, reviu dan pengujian efektivitas sistem pengendalian intern. Inspektorat dalam melaksanakan tupoksinya terkait sub unsur evaluasi terpisah berdasarkan Program Kerja Pemeriksaan Tahunan (PKPT) yang telah disusun.

Berdasarkan hasil wawancara dan studi dokumentasi, permasalahan yang ditemukan terkait dengan evaluasi terpisah adalah Standar Operasional Prosedur (SOP) yang belum lengkap. Meskipun telah dituangkan dalam PKPT, Inspektorat sebagai pengawas internal di daerah belum menyusun SOP tentang evaluasi terpisah dan belum melakukan sosialisasi atas pelaksanaannya di SKPD. Kegiatan evaluasi yang selama ini dilakukan masih bersifat komprehensif atau keseluruhan dan hanya fokus pada pertanggunjawaban dan pelaporan. Mekanisme reviu atas temuan yang dilakukan saat ini adalah kegiatan tindak lanjut atas temuan audit.

Menurut Mardiasmo (2009:205) sistem dan prosedur merupakan rangkaian kegiatan atau aktivitas untuk menelaah struktur pengendalian, efektivitas, ketepatan, logika dan kebutuhan suatu organisasi. Salah satu contoh sistem dan prosedur yang biasa digunakan adalah Standard Operating Procedures (SOP) yang menjelaskan bagaimana sebuah fungsi dan tanggung jawab dilaksanakan. Beberapa kegiatan utama di SKPD belum dilengkapi dengan SOP seperti belum ada SOP pelaksanaan kegiatan evaluasi terpisah dan SOP pelaksanaan kegiatan tindak lanjut pada Inspektorat. Hal ini tidak sesuai dengan Peraturan Kepala BPKP Nomor 4 Tahun 2016 tentang pedoman penilaian dan strategi peningkatan maturitas SPIP, bahwa penerapan SPIP di suatu instansi harus berdasarkan kebijakan/SOP yang menjadi acuan pelaksanaan kegiatan di instansi.

Suwanda dan Dailibas (2016:155) SOP adalah serangkaian instruksi tertulis yang dibakukan mengenai berbagai proses penyelenggaraan administrasi pemerintahan, yaitu bagaimana, kapan, di mana, dan siapa yang harus melaksanakannya. Dengan SOP seluruh pelaksanaan kegiatan di instansi pemerintah akan memiliki standar pelaksanaan, waktu dan pelaksananya. Ketika terjadi masalah dalam pelaksanaan pekerjaan, akan mudah diketahui siapa dan apa yang menjadi penyebabnya. Hal ini sejalan dengan penelitian yang dilakukan sebelumnya oleh Hindriani (2012) di Dinas Kesehatan Kabupaten Madiun yang menyimpulkan bahwa proses internalisasi SPIP perlu didukung dengan penerapan pengawasan ketat berupa Standar Operasional Prosedur (SOP).

\section{Kendala Penerapan SPIP di Kabupaten Gorontalo}

Ada 6 (enam) kendala yang ditemukan dalam penerapan SPIP di Kabupaten Gorontalo yaitu: 1) kompetensi SDM belum memadai; 2) kuantitas SDM belum sesuai dengan kebutuhan organisasi; 3) terbatasnya anggaran; 4) kurangnya kepatuhan; 5) belum maksimalnya kegiatan evaluasi dan dokumentasi; dan 6) terdapat kegiatan yang belum didukung dengan Standar Operasional Prosedur (SOP).

\section{Upaya-upaya yang Dilakukan Dalam Mengatasi Kendala Penerapan SPIP untuk Peningkatan Tingkat Maturitas SPIP di Kabupaten Gorontalo}

Pemerintah Kabupaten Gorontalo melalui Inspektorat yang merupakan suatu lembaga dengan kewenangannya melaksanakan fungsi pengawasan internal di pemerintah daerah yaitu berupa pengawasan, pemeriksaan dan pengendalian terhadap pelaksanaan urusan pemerintah daerah secara konsisten terus berupaya melakukan perbaikan untuk mengatasi kendala yang terjadi. Tujuan dari perbaikan tersebut adalah meningkatkan tingkat maturitas SPIP dari level 2 "berkembang” menjadi level 3 "terdefinisi”. Beberapa upaya tersebut diuraikan sebagai berikut: 
a. Upaya yang dilakukan terkait unsur lingkungan pengendalian yaitu, program pengembangan SDM melalui diklat khususnya terkait dengan substansi teknis. Selain perencanaan diklat, upaya yang dilakukan adalah Pelatihan Kantor Sendiri (PKS) agar pegawai yang belum mengikuti diklat mempunyai pengetahuan yang sama dengan pegawai yang telah mengikuti diklat. Skala prioritas juga diterapkan dalam penyusunan anggaran khususnya terkait dengan peningkatan kompetensi SDM. SKPD mengutamakan program dan kegiatan yang sifatnya penting dan mendesak. Pemerintah Kabupaten Gorontalo juga berupaya membangun komunikasi yang efektif dalam mensosialisasikan kebijakan atau aturan baru.

b. Upaya yang dilakukan terkait unsur penilaian risiko, yaitu Pemerintah Kabupaten Gorontalo melalui Inspektorat bekerja sama dengan BPKP Perwakilan Provinsi Gorontalo melakukan diklat SPIP tentang penilaian risiko yang diikuti oleh satgas SPIP SKPD. Selain itu mengkomunikasikan kembali dengan seluruh penanggung jawab kegiatan di SKPD perihal register risiko dan rencana tindak pengendalian (RTP) yang telah ada melalui rapat atau focus group discussions (FGD).

c. Upaya yang dilakukan terkait unsur informasi dan komunikasi, yaitu pendampingan terhadap pengelola sistem informasi yang ada di SKPD.

d. Upaya yang dilakukan terkait unsur pemantauan, dilakukan penambahan jumlah auditor dan membangun komitmen organisasi atas pelaksanaan kegiatan evaluasi terpisah.

\section{Penutup}

Kesimpulan dalam penelitian ini adalah: 1) Pemerintah Kabupaten Gorontalo telah menerapkan SPIP dan secara umum telah sesuai dengan PP 60 Tahun 2008 tentang SPIP, namun terdapat beberapa kendala dalam penerapannya. Kendala ini terjadi pada empat unsur dari 5(lima) unsur SPIP. Hal ini yang menyebabkan tingkat maturitas SPIP masih berada pada level 2 atau level berkembang; 2) kendala dalam penerapan SPIP adalah kompetensi SDM belum memadai, kuantitas SDM belum sesuai dengan kebutuhan organisasi, terbatasnya anggaran, kurangnya kepatuhan, belum maksimalnya kegiatan evaluasi dan dokumentasi dan terdapat kegiatan yang belum didukung dengan Standar Operasional Prosedur (SOP); 3) upaya yang dilakukan Pemerintah Kabupaten Gorontalo yaitu program pengembangan SDM melalui diklat substantif dan pelatihan kantor sendiri, memaksimalkan anggaran, membangun komunikasi yang efektif, menambah jumlah auditor dan membangun komitmen organisasi.

Saran yang dapat diberikan dari penelitian ini yaitu : 1) perlu menyusun data pegawai beserta diklat teknis yang pernah diikuti dan dijadikan sebagai bahan pertimbangan dalam melakukan rotasi pegawai. Ini sebagai bentuk komitmen pemerintah, dalam penempatan pegawai sesuai dengan kompetensi yang dipersyaratkan; 2) perlu melakukan penyusunan identifikasi risiko dan Rencana Tindak Pengendalian (RTP) di semua kegiatan utama SKPD dan melakukan pemutakhiran kembali register risiko dan Rencana Tindak Pengendalian (RTP) yang telah disusun secara konsisten dan berkelanjutan; 3) perlu memasukkan rencana penyediaan informasi berbasis aplikasi serta pengembangannya pada renstra masing-masing SKPD; 4) perlu membuat berita acara kesepakatan penyelesaian temuan antara auditor dengan obyek pemeriksaan; 5) Pemerintah Kabupaten Gorontalo melalui Inspektorat perlu membangun struktur pelaksanaan evaluasi terpisah mulai dari penyusunan SOP dan mensosialisasikannya kepada seluruh pegawai, penguatan kapasitas auditor, mensosialisasikan kegiatan evaluasi terpisah kepada SKPD.

\section{Daftar Pustaka}

Badan Pemeriksa Keuangan Republik Indonesia. 2016. Ikhtisar Hasil Pemeriksaan Semester I.

Badan Pengawas Keuangan dan Pembangunan. 2017. Paparan Deputi Kepala BPKP Bidang Pengawasan Penyelenggaraan Keuangan Daerah pada Rakornas APIP Tahun 2017.

Edison, Emron., Anwar, Yohny dan Komariyah, Imas. 2016. Manajemen Sumber Daya Manusia. Cetakan kesatu. Alfabeta Bandung.

Fahmi, Irham. 2015. Pengantar Ilmu Administrasi Bisnis. Cetakan Kesatu. CV. Alfabeta Bandung.

Gunawan, Imam. 2016. Metode Penelitian Kualitatif: Teori dan Praktik. Edisi kesatu, Cetakan keempat. PT. Bumi Aksara. Jakarta.

Hindriani, Nuning. 2012. Sistem Pengendalian Intern Pemerintah (SPIP) pada Perencanaan dan Pelaksanaan Anggaran di Daerah (Studi Pada Dinas Kesehatan Kabupaten Madiun). Magister Jurusan Administrasi Publik, Fakultas Ilmu Administrasi, Universitas Brawijaya. Jurnal ISSN: 1411-0199. Vol. 15 No. 3. 
Kamarudin, Jamaludin. 2015. Evaluasi Sistem Pengendalian Intern Pemerintah Dalam Pemungutan Retribusi dan Parkir pada Kabupaten Sleman. Magister Jurusan Akuntansi, Fakultas Ekonomi dan Bisnis, Universitas Gadjah Mada.

Kusmandhani, Yogi. 2015. Analisis Sistem Pengendalian Intern Pemerintah Dalam Pelaksanaan Pencairan Anggaran Belanja Negara pada Kantor Pelayanan Perbendaharaan Negara Jakarta IV. Magister Jurusan Akuntansi, Fakultas Ekonomi dan Bisnis, Universitas Gadjah Mada.

Mahiri, A. Eli. 2016. Pengaruh Pendelegasian Wewenang dan Komitmen Organisasi Terhadap Prestasi Kerja Pegawai Dinas Pendidikan Kabupaten Majalengka. Jurnal Ilmiah Manajemen dan Akuntansi. ISSN 2356-3923, Volume 3, No. 1.

Mardiasmo. 2009. Akuntansi Sektor Publik. CV Andi Offset.

Mulyadi, Deddy. 2016. Studi Kebijakan Publik dan Pelayanan Publik. CV.Alfabeta. Bandung.

Parsons, Wayne. 2006. Publik Policy: Pengantar Teori dan Praktik Analisis Kebijakan. Kencana.

Peraturan Pemerintah Nomor 60 Tahun 2008 tentang Sistem Pengendalian Intern Pemerintah.

Peraturan Kepala Badan Pengawas Keuangan dan Pembangunan. 2009. Nomor: PER-1326/K/LB/2009 tentang Pedoman Teknis Penyelenggaraan SPIP Sub Unsur Delegasi Wewenang dan Tanggung Jawab.

\footnotetext{
----------------- tentang Pedoman Teknis Penyelenggaraan SPIP Sub Unsur Identifikasi Risiko.

-------------- tentang Pedoman Teknis Penyelenggaraan SPIP Sub Unsur Analisis Risiko.

---------------- tentang Pedoman Teknis Penyelenggaraan SPIP Sub Unsur Pemantauan Berkelanjutan.

-------------- tentang Pedoman Teknis Penyelenggaraan SPIP Sub Unsur Evaluasi Terpisah.
----------------. 2016. Nomor 4 Tahun tentang Pedoman Penilaian dan Strategi Peningkatan Maturitas SPIP.

Pusdiklatwas BPKP. 2009. Modul Diklat Sistem Pengendalian Intern Pemerintah.

-------. 2013. Modul Penyelenggaraan Sistem Pengendalian Intern Pemerintah Integratif.

Sedarmayanti. 2011. Membangun dan Mengembangkan Kepemimpinan serta Meningkatkan Kinerja untuk Meraih Keberhasilan. PT. Refika Aditama Bandung.

Sugiyono. 2015. Memahami Penelitian Kualitatif, CV.Alfabeta. Bandung.

Suwanda, Dadang dan Dailibas. 2016. Panduan Penerapan Sistem Pengendalian Intern Pemerintah, Gramedia.

Torang, Syamsir. 2012. Metode Riset Struktur dan Perilaku Organisasi. CVAlfabeta, Bandung.

Undang-Undang Nomor 17 Tahun 2003 tentang Keuangan Negara.

Undang-Undang Nomor 1 Tahun 2004 tentang Perbendaharaan Negara.

Undang-Undang Nomor 15 Tahun 2004 tentang Pemeriksaan Pengelolaan dan Tanggung Jawab Pengelolaan Keuangan Negara.

Wibowo. 2015. Perilaku Dalam Organisasi. PT. Rajagrafindo Persada. 